\title{
KONSEP NUSHUZ DALAM CLD KHI
}

\author{
Kafa Bihi
}

\author{
Ketegan RT 01 RW 01, Kecamatan Tanggulangin Kabupaten \\ Sidoarjo.Email: kafa_bihi@gmail.com
}

\begin{abstract}
In the Compilation of Islamic Law, the term of nushuz means a wife who does not perform her duty to a husband. But it is not set about the busband's nushuz. as firmly as that of the wife. The Compilation of Islamic Law is considered unfair by gender activists so that the Gender Mainstreaming Working Group of the Department of Religion launched a script called Counter Legal Draft of Islamic Law Compilation (CLD-KHI). This paper examines CLD-KHI's offer of nushuz using the perspective of Islamic law, ie the views of some Muslim scholars about nushu: Nushur, as arranged in CLD KHI, applies to husband and wife. The settlement of nushur is carried out by mean of peace, both by the wife and husband. The reason is because between the right and obligation of both are equal. The concept of nushuz in CLD-KHI is not in accordance with Islamic law, because nushuz is caused by one of the parties who does not perform the obligation or violate the rights of his/ her partner. Of these rights and obligations, CLD KHI make them equal. While in Islamic Law, the rights and obligations of husband and wife are different. There is a difference between the provisions in Islamic law and CLD-KHI's. In Islamic Law, the settlement of nushuz performed by a wife has three stages, they are advising, leaving in bed, and hitting with a punch that is not hard. While the effect of nushur in CLD KHI is not clearly explained.
\end{abstract}

Keywords: Nushuz and CLD-KHI.

Abstrak: Dalam Kompilasi Hukum Islam, istilah Nushuz bermakna istri yang tidak melakukan kewajibannya terhadap suami. Akan tetapi tidak diatur mengenai Nushuz suami secara tegas seperti pada istri. Kompilasi Hukum Islam dinilai kurang adil oleh para aktivis gender sehingga Kelompok Kerja Pengarusutamaan Gender Departemen Agama RI meluncurkan naskah yang disebut Counter Legal Draft Kompilasi Hukum Islam (CLD-KHI). Tulisan ini mengkaji tawaran CLD-KHI tentang nushuz dengan menggunakan perspektif hukum Islam, yaitu qaul fuqaha tentang nushuz: Nushuz yang diatur dalam CLD KHI berlaku bagi suami maupun istri. Penyelesaian Nushuz dilakukan dengan cara perdamaian, baik yang dilakukan oleh pihak istri maupun suami. Hal ini dikarenakan antara hak dan kewajiban keduanya setara. Konsep Nushuz dalam CLDKHI, tidak sesuai dengan hukum Islam, karena adanya Nushuz disebabkan oleh salah satu pihak yang tidak melaksanakan kewajiban atau melanggar hak pasangannya. Dari hak dan kewajiban inilah yang tidak sama, dalam CLD KHI mensetarakan keduanya, sedangkan dalam Hukum Islam hak dan kewajiban suami istri berbeda. Selanjutnya

\section{AL-HUKAMA}

The Indonesian Journal of Islamic Family Law

Volume 07, Nomor 01, Juni 2017; ISSN:2089-7480 
mengenai cara penyelesaian nushuz tidak sama. Dalam Hukum Islam penyelesaian Nushuz yang dilakukan oleh istri ada tiga tahap, yakni mulai menasehati, meninggalkan di tempat tidur, dan memukul dengan pukulan yang tidak keras Begitu juga dengan akibat Nushur, dalam CLD KHI tidak dijelaskan.

Kata Kunci: Nushuz dan CLD-KHI

\section{Pendahuluan}

Setelah akad nikah sah, seorang laki-laki yang menjadi suami memperolah berbagai hak dalam keluarga, seorang perempuan yang menjadi istri memperoleh berbagai hak pula. Di samping itu, mereka juga memikul kewajiban-kewajiban sebagai akibat mengikatkan diri dalam perkawinan itu. Salah satu kewajiban suami terhadap istri adalah menafkahi, sementara istri wajib patuh kepada suami dalam hal-hal yang tidak maksiat. ${ }^{1}$

Apabila antara hak dan kewajiban itu tidak sesuai dengan yang ditentukan dalam perjanjian, maka akan menimbulkan perselisihan. Munculnya perselisihan dan perbedaan pandangan antara suami dan istri adalah suatu kewajaran, namun yang terpenting dari itu semua adalah bagaimana suami dan istri mensikapinya dengan satu komitmen, yaitu kasih sayang untuk mempertahankan dan menyelamatkan hubungan rumah tangga. ${ }^{2}$

Kenyataan menunjukkan, adakalanya pasangan suami istri tidak konsisten dengan hak dan kewajiban mereka sehingga berakibat tidak tercapainya tujuan perkawinan yang seringkali berakhir dengan perceraian. Salah satu penyebab perselisihan dalam rumah tangga adalah ketidaktaatan yang dilakukan oleh seorang istri kepada suaminya. Ketidaktaatan atau pembangkangan dalam islam diistilahkan dengan nushuz. Nushuz mempunyai arti durhaka, maksudnya seorang istri melakukan perbuatan yang menentang suami tanpa alasan yang dapat diterima oleh syara'. Ia tidak menaati suaminya, atau menolak diajak ke tempat tidur. ${ }^{3}$

1 Abdul Rahman Ghozali, Figh Munakahat, Jakarta: Kencana Perdana Media Grup, 2012), 158.

2 Muhammad Al Baqir, Menyingkap Hakikat Perkawinan, (Bandung: Penerbit Karisma, 1997), 9.

3 Slamet Abidin dan Aminuddin, Fiqih Munakahat I, (Bandung: CV. Pustaka Setia, 1999),185. 
Dalam Kompilasi Hukum Islam pasal 84 ayat (1) dijelaskan, bahwa "istri dapat dikatakan nushuz jika ia tidak mau melaksanakan kewajiban-kewajiban sebagaimana dimaksud dalam pasal 83 ayat (1) kecuali dengan alasan yang sah". ${ }^{4}$ Istilah nushuz memang hanya terpaku pada seorang istri yang tidak melakukan kewajibannya terhadap suami. Akan tetapi tidak diatur secara tegas mengenai nushuz suami sebagaimana aturan untuk istri. Jika suami nushuz, tidak dinyatakan gugurnya hak suami terhadap istri, atau kewajiban istri terhadap suami, sebagai konsekuensi/sanksinya.

Pasal yang terdapat pada Kompilasi Hukum Islam mengenai nushuz dinilai kurang adil oleh para aktivis gender. Pada 4 Oktober 2004 Kelompok Kerja Pengarusutamaan Gender Departemen Agama RI yang selanjutnya disebut Pokja PUG Depag, meluncurkan naskah tandingan rumusan hukum Islam yang disebut Counter Legal Draft Kompilasi Hukum Islam (CLD-KHI). ${ }^{5}$ Naskah ini, sebagaimana pengakuan tim penyusun CLD-KHI menawarkan sejumlah pemikiran pembaruan hukum keluarga Islam yang disusun dalam RUU Hukum Perkawinan Islam, RUU Hukum kewarisan Islam, dan RUU Hukum Perwakafan Islam.

Menurut Counter Legal Draft Kompilasi Hukum Islam pada pasal 1 ayat (13) dijelaskan, bahwa "nushuz adalah pembangkangan suami atau istri terhadap pasangannya karena tidak melaksanakan kewajiban sebagai suami atau istri atau melanggar hak pasangannya". ${ }^{6}$ Counter Legal Draft Kompilasi Hukum Islam tidak memberlakukan nushuz hanya kepada istri yang tidak melaksanakan kewajiban atau melanggar hak suami, melainkan juga terhadap suami yang tidak melaksanakan kewajibannya atau melanggar hak istri.

Demikian juga menurut beberapa ahli fikih, ada yang berpendapat bahwa istilah nushuz itu hanya melekat pada diri istri dan tidak dikatakan pada diri suami, padahal secara logika suami itu juga adalah manusia biasa yang tidak mungkin akan terlepas dari

${ }^{4}$ Departemen Agama R.I, Bahan Penyuluhan Hukum, Jakarta: Direktorat Jenderal Pembinaan Kelembagaan Agama Islam, 1999, 151.

${ }^{5}$ Marzuki Wahid, Fiqh Indonesia, (Bandung: Marja, 2014), 200.

6 Tim Pengarusutamaan Gender Departemen Agama RI, Pembaruan Hukum Islam: Counter Legal Draft Kompilasi Hukum Islam, (Jakarta: 2004), 35. 
sikap lalai, khilaf, dan salah. Ketentuan nushuг dalam KHI tersebut dirasakan membawa ketidakadilan, karena ketika suami tidak dapat memenuhi kewajibannya (nushus), tidak ditentukan sanksinya. Sedangkan ketika istri dianggap telah nushuz, maka hak istri gugur untuk menuntut kewajiban suami, terutama mendapatkan nafkah dengan alasan bahwa, "pemberian nafkah kepada istri merupakan imbalan dari bolehnya suami bersenang-senang dengan istri.

Berdasarkan penalaran di atas, menarik kiranya mengkaji konsep Counter Legal Drafting Kompilasi hukum Islam tentang nusyuz dari sudut pandang pendapat para fiqaha.

\section{Hak dan Kewajiban Suami Istri dalam Islam}

Setiap orang tentu memiliki hak dan kewajiban dalam kehidupannya. Dalam pernikahan juga terdapat hak dan kewajiban antara suami dan istri, yang mana keduanya saling melengkapi demi kelangsungan hidup berkeluarga. Hak ialah sesuatu yang dapat dimiliki atau dikuasai, sedangkan kewajiban ialah sesuatu yang harus diberikan, baik berupa benda maupun berupa perbuatan. ${ }^{8}$

Dalam Hadits Nabi Saw. Dijelaskan mengenai hak dan kewajiban suami istri:

"Telah menceritakan kepada kami Al Hasan bin Ali Al Khallal, telah menceritakan kepada Al Husain bin Ali Al Ju'fi dari Za'idah dari Syabib bin Gharqadah dari Sulaiman bin Amr bin Al Abwash berkata; Telah menceritakan kepadaku Bapakku bahwa dia melaksanakan haji wada' bersama Nabi shallallahu 'alaibi wasallam. Beliau bertabmid dan memuji Allah, beliau memberi pengingatan dan nasehat. Beliau menuturkan cerita dalam haditsnya, lantas bersabda: "Ketahuilah, berbuat baiklah terbadap wanita, karena mereka adalah tawanan kalian. Kalian tidak berbak atas mereka lebih dari itu, kecuali jika mereka melakukan perbuatan keji yang nyata. Jika mereka melakukannya, jaubilah mereka di tempat tidur dan pukullah mereka dengan pukulan yang tidak menyakitkan. Jika kemudian mereka menaatimu, maka janganlah kamu mencari-cari jalan untuk menyusabkannya. Ketabuilab; kalian memiliki hake atas istri kalian dan istri kalian memiliki hak atas kalian. Hak kalian atas istri kalian ialah

7 Wahbah az-Zuhayly, al-Fiqh al-Islam wa Adillatuh, (Damaskus: Dar alFikr,1997), 779.

${ }^{8}$ Ibnu Mas'ud dan Zainal Abidin, Fiqh Madzhab Syafi'i 2,(Bandung: Pustaka Setia, 2007), 312. 
dia tidak boleh memasukean orang yang kalian benci ke tempat tidur kalian. Tidak boleh memasukan seseorang yang kalian benci ke dalam rumah kalian. Ketahuilab; hak istri kalian atas kalian ialah kalian berbuat baik. kepada mereka dalam (memberikan) pakaian dan makanan (kepada) mereka".

Suami istri mempunyai kewajiban bersama dalam rumah tangga, kewajiban tersebut adalah :

1. Sopan dalam perkataan dan perbuatan dan jangan adayang memulai menyinggung perasaan;

2. Menanamkan kesabaran dan tidak cepat marah;

3. Berusaha mencari kesenangan bersama yang sesuai dengan ajaran agama Islam;

4. Tidak terlalu cemburu pada masalah yang tidak patut dicemburui. ${ }^{10}$

Adapun pemisahan secara rinci, antara suami dan istri mempunyai hak dan kewajiban tersendiri. Hak suami atas istri adalah sebagai berikut:

1. Menjaga kehormatannya lahir dan batin apabila ada gangguan dari orang yang bukan muhrimnya;

2. Tunduk pada aturan-aturan suami di jalan yang hak, sedikitpun tak boleh menyangkalnya;

3. Tidak mengizinkan laki-laki lain masuk ke dalam kamarnya kecuali atas izin suaminya;

4. Apabila suami hendak bersetubuh, janganlah ditolak dan tidak boleh pula merasa enggan;

5. Tidak mengerjakan puasa sunnah kalau tidak seizin suaminya, karena terkadang datang hajatnya pada siang hari untuk bersetubuh;

6. Jangan menyakiti hati suami dengan lidah dan perbuatan, seperti berkata tidak sopan terhadap suami.

7. Melarang istri keluar rumah bila tidak ada keperluan atau seizin suami.11

9 Sahih Bukhari, Kitab Sembilan Imam Hadits, No. 3179 lidwa pusaka i-software www.lidwapusaka.com

${ }_{10}$ Ibnu Mas'ud dan Zainal Abidin, Figh Madz̧hab Syafi'i 2,(Bandung: Pustaka Setia, 2007), 313.

${ }^{11}$ Ibnu Mas’ud dan Zainal Abidin, Fiqh Madz̧hab Syafïi 2, 320. 
Apabila suami mempunyai hak dan kewajiban, seorang istri juga mempunyai hak dan kewajiban. Adapun hak istri kepada suami adalah sebagai berikut :

1. Dipergauli dengan pergaulan yang baik.

2. Tidak diperlakukan terlalu keras, karena pada umumnya wanita itu mudah patah hatinya dan lekas menjadi kesal;

3. Memperoleh nafkah, pakaian, makanan, dan minumannya serta tempat tinggal yang sesuai dengan kemampuan;

4. Tidak dipukul dan ditampar bagian badannya. ${ }^{12}$

Semua tugas suami dan istri wajib dilakukan selagi tidak ada halangan menurut agama. Suami sebagai pemimpin rumah tangga wajib menuntun keluarganya dalam ajaran agama Islam. Tak luput pula seorang istri yang senantiasa harus patuh kepada suaminya selagi dalam hal kebaikan.

\section{Konsep Fuqaha Tentang Nushuz}

Lafadz nushuz merupakan masdar dari kata nashaza, yang berarti tanah yang tersembul tinggi ke atas. ${ }^{13}$ Menurut al-Qurtubi, nushuz berarti menentang, diambil dari kata an-nashzu yang artinya bagian bumi yang tinggi. ${ }^{14}$ Kata nushuz mempunyai arti durhaka atau tidak patuh, yakni pembangkangan seorang istri terhadap suaminya dan sebaliknya. ${ }^{15}$

Imam Syafi'i dalam kitabnya al-Umm, tidak memberikan pengertian khusus mengenai nushuz istri. Akan tetapi hanya menggambarkan nushuz suami, yaitu suami yang membenci istrinya. ${ }^{16}$ Menurut Imam Nawawi, istri yang nushur adalah istri yang durhaka pada suaminya dan enggan terhadapnya. Sedangkan suami yang nusbuz adalah suami yang meninggalkan istri dan membencinya. ${ }^{17}$ Muhammad Abduh sebagaimana dikutip

\footnotetext{
12 Ibnu Mas'ud dan Zainal Abidin, Fiqh Madzhab Syafi'i 2, 318.

${ }^{13}$ Ibn manzur, Lisan al-'Arab, juz 7, ( Bairut: Dar al-Misriyyah, 1999), 284.

${ }^{14}$ Al Qurtubi, al-Jami' Li abkam al-Qur'an, juz 5, (Bairut: Dar al-Fikr, 2000), 149.

15 Abdul Aziz Dahlan et al, Ensiklopedi Islam, jilid 4,(Jakarta: Ichtiar Baru Van Hoeve, 2005), 232.

16 Abu Abdillah Muhammad bin Idris al-Syafi'i, al-Umm, (Bairut: Dar al-Fikr, 1999), 203

17 Abu Zakaria Muhy al-Din bin Syaraf al-Nawawi, al-Majmu' sharb almuhadhdhab, vol.16, ( Bairut: Dar al-Fikr, t.t), 445.
} 
Muhammad Rashid Ridha menjelaskan, bahwa nushur adalah tindakan istri yang tidak memenuhi hak suaminya dan berusaha memposisikan dirinya di atas kepala keluarga. ${ }^{18}$

Slamet abidin menyatakan dalam bukunya Fiqh Munakahat 1, bahwa nushuг mempunyai arti durhaka, maksudnya seorang istri melakukan perbuatan yang menentang suami tanpa alasan yang dapat diterima oleh syara'. Ia tidak menaati suaminya, atau menolak diajak ke tempat tidurnya. ${ }^{19}$ Wahbah az-Zuhayly menjelaskan, bahwa nushuz merupakan ketidakpatuhan salah satu pasangan terhadap apa yang seharusnya dipatuhi, kebencian terhadap pasangannya, dan keluarnya istri dari rumah tanpa izin suami, kecuali pergi menemui hakim untuk menuntut haknya. Nushuz. dapat terjadi dalam bentuk perbuatan maupun ucapan. ${ }^{20}$

Dalam literatur lain dijelaskan, bahwa nushuz adalah sikap membangkang atau durhaka istri kepada suaminya, bahkan membantah dan tidak taat kepada suaminya atau terjadi penyelewengan-penyelewengan yang tidak dibenarkan oleh suami. ${ }^{21}$ Ulama Syafi'iyah yang lain, ada yang dengan tegas memberi pengertian nushuz dengan keluar dari ketaatan secara mutlak, baik dilakukan oleh suami maupun istri. ${ }^{22}$

Dari berbagai pendapat di atas, dapat disimpulkan bahwa, nushuz adalah sikap suami atau istri meninggalkan kewajibannya sehingga menimbulkan ketegangan hubungan rumah tangga. Nushur muncul karena ada suatu persoalan yang terjadi antara suami istri dalam rumah tangga tersebut. Mungkin salah satu di antara mereka merasa tidak puas dengan sikap dan tingkah laku yang lain, sehingga ganjalan ini menimbulkan perubahan sikap salah seorang di antara keduanya. ${ }^{23}$

18 M.Rasyid Ridha, al-Nida' li al-Jinsi al-Latif, A.Rivai Usman, Perempuan Sebagai Kekasih, (Jakarta: Hikmah, 2004), 80.

${ }^{19}$ Slamet Abidin dan Aminuddin, Fiqih Munakahat I, 185.

${ }^{20}$ Wahbah az-Zuhayly, al-Fiqh al-Islamy wa Adillatuh, (Damaskus: Dar al-Fikr, 1997), 6855.

${ }^{21}$ Sudarsono, Pokok-Pokok Hukum Islam,(Jakarta: Rineka Cipta, 1992), 248.

22 Ibrahim al-bajurii, Hashiyah al-Bajuri ala Ibn al-Qasim al-Ghazi, vol.2, (Bairut:

Dar al-Kutub al-Ilmiyyah, t.t), 129.

${ }^{23}$ Abdul Aziz Dahlan et al, Ensiklopedi Islam, jilid 4, 232. 
Nushuz adakalanya dilakukan oleh istri, adakalanya juga dilakukan oleh suami.

1. Nushuz istri

Istri yang nushuz adalah yang durhaka kepada suami dan tidak taat kepadanya, atau menolak ajakan ke tempat tidur, atau keluar rumah tanpa izin. ${ }^{24}$ Dengan kata lain, istri tidak melakukan kewajibannya.

As-Syarakhsi dalam kitabnya al-Mathbut menjelaskan, bahwa istri yang nushuz adalah istri yang meninggalkan rumah suaminya atau istri yang menolak untuk tinggal bersama di rumah suaminya atau istri yang menolak pindah ke suatu tempat sesuai keinginan suami, sementara suami sudah melunasi atau menyerahkan semua mahar istrinya. ${ }^{25}$

Imam Syafi'i menjelaskan, bahwa istri dapat dikatakan nushur, jika :

a. Istri keluar dari rumah

Istri keluar dari rumah tanpa ada izin dari suami. Kecuali Jika keluar rumah bersama suami atau karena memenuhi kebutuhan suami

b. Istri tidak mau digauli

Istri enggan ketika akan digauli dengan alasan yang tidak dibenarkan dalam agama.

c. Istri berangkat haji

Istri yang berangkat haji tanpa izin dari suami. ${ }^{26}$

Imam Abu Hanifah juga mengategorikan istri dikatakan nushuг apabila :

a. Istri keluar dari rumah;

b. Istri menolak pindah rumah;

Yaitu apabila isteri menolak untuk pindah ke rumah kediaman bersama tanpa sebab yang dapat dibenarkan secara shar'i, padahal suami telah mengajak pindah ke tempat

${ }^{24}$ Sayyid Sabiq, Fiqh Sunnah, Jilid 3, Abu Syauqina dan Abu Aulia Rahma, Jilid 3,(Jakarta: Tinta Abadi Gemilang, 2003), 482.

25 Shams ad-Din as-Sharakhsi, al-Mabsut, vol 5,(Beirut: Dar al-Kutub al-Ilmiyyah, 1993), 186

26 Al-Bagawi, at-Tahdziib fi Fiqh al-Imam asy-Syafi'i, (Beirut: Dar al-Kutub alIlmiyyah, 1997), 545. 
kediman bersama, sedang tempat kediaman bersama (tempat tinggal) tersebut merupakan tempat tinggal yang layak bagi dirinya.

c. Berangkat haji;

d. Wanita karir. ${ }^{27}$

Yaitu jika istri keluar untuk memenuhi karirnya, akan tetapi suami tidak mengizinkan, dan istri tidak menghiraukan larangan suaminya tersebut, dalam artian tetap keluar rumah untuk memenuhi karirnya.

2. Nushuz Suami

Nushuz suami mengandung arti pendurhakaan suami kepada Allah Swt. Karena meninggalkan kewajibannya terhadap istrinya. ${ }^{28}$ Nushur suami terjadi bila ia tidak melaksanakan kewajiban terhadap istrinya, baik meninggalkan kewajiban yang bersifat materi (nafkah) atau meninggalkan kewajiban yang bersifat non-materi (menggauli istri dengan baik), seperti berlaku kasar, menyakiti fisik dan mental istri, tidak melakukan hubungan badaniyah dalam waktu tertentu dan tindakan lain yang bertentangan dengan asas pergaulan baik. ${ }^{29}$

Imam Syafi'i mengategorika suami dikatakan nushu>z apabila:

a. Tidak mau memberi nafkah;

b. Tidak mau menggauli istri;

c. Menyakiti istri, seperti memukul dengan tanpa alasan;

d. Bersikap acuh tak acuh. ${ }^{30}$

Nushur, yang timbul dari suami dianggap sebagai suatu keterpaksaan. Sikap nushuz suami merupakan puncak dari

27 Abu Zakaria Muhyi al-Din bin Syaraf al-Nawawi, al-Majmun' Sharh alMuhadhdhab, vol.16, (Beirut: Dar al-Fikr, t.t), 446.

28 Amir Syarifuddin, Hukum Perkawinan Islam di Indonesia, (Jakarta: Kencana, 2009), 193.

${ }^{29}$ Ibid,.

30 Al-Bagawi, at-Tabdziïb fi Fiqh al-Imam asy-Syafi'i, (Beirut: Dar al-Kutub alIlmiyyah, 1997). 545. 
keadaan istri yang dianggapnya tidak dapat membahagiakan rumah tangganya. ${ }^{31}$

\section{Cara Penyelesaian Nushuz}

Penyelesaian nushuz yang dilakukan oleh istri ataupun suami dijelaskan dalam al-Qur'an. Untuk nushuz, yang dilakukan oleh istri, apabila ia telah kelihatan durhaka terhadap suaminya, hendaklah suaminya melakukan hal sebagaimana dalam al-Qur'an surat anNisa' ayat 34: "Maka nasehatilah mereka dan pisabkanlah mereka di tempat tidur mereka, dan pukullah mereka. kemudian jika mereka mentaatimu, Maka janganlah kamu mencari-cari jalan untuk menyusabkannya. Sesunggubnya Allab Maha Tinggi lagi Maha besar, ${ }^{32}$

1. فَعَظُو هُنَ maka nasihatilah mereka

Nasihatilah mereka tentang apa yang diwajibkan Allah Swt. Terhadap mereka, berupa ketaatan dan pergaulan yang baik. Menasihati dalam hal ini merupakan sebuah teguran dengan kata-kata yang sopan dan lemah lembut serta secara perikemanusiaan, dalam arti tidak menimbulkan kejengkelan. ${ }^{33}$ Imam al-Ghazali dalam kitabnya Ibya' 'Ulumu al-Din menjelaskan bahwa apabila nushuz itu khusus dari wanita maka laki-laki itu penegak atas wanita. Ia berhak mendidiknya dan membawanya ketaatan secara paksa. ${ }^{34}$

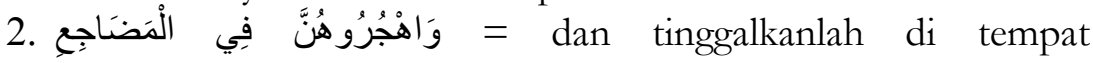
pembaringan

Langkah kedua, suami harus menghindarinya di tempat tidur atau tidak tidur bersama istri dalam satu selimut. Pendapat lain menjelaskan, bahwa maksud meninggalkan di tempat adalah memalingkan punggung suami di tempat tidur atau ia menyendiri, tidak meninggalkan rumah. ${ }^{35}$ Tindakan ini dilakukan apabila setelah dinasihati tidak juga menghentikan

31 Abdul Aziz Dahlan et al, Ensiklopedi Islam, jilid 4, Jakarta: Ichtiar Baru Van Hoeve), 2005233.

32 Kementerian Agama RI, al-Qur'an dan Terjemahnya, (Bandung: Diponegoro, 2009),80.

33 Ibnu Mas'ud dan Zainal Abidin, Fiqh Madzhab Syafi'i 2, (Bandung: Pustaka Setia, 2007),334.

${ }^{34}$ Imam al-Ghazali, Ibya' 'Ulumu al-Din, Zuhri, (Semarang: asy-Syifa', 2003), 160.

35 Ibid,. 
kedurhakaannya. Muhammad Rasyid Ridha mengartikan, bahwa adalah tempat tidur bersama dengan istri. Sedangkan sikap pisah kamar atau tidur tidak seranjang malah bisa memperburuk hubungan keduanya. Tidur seranjang dengan istri dalam keadaan sikap dingin, diharapkan dapat menyadarkan sang istri agar istri tidak lagi meremehkan suami serta mampu membuat istri kembali pada ketaatan semula. ${ }^{36}$

Quraish Shihab menjelaskan dalam bukunya Tafsir alMisbah, bahwa keberadaan di kamar membatasi perselisihan itu, karena keberadaan dalam kamar adalah untuk menunjukkan ketidaksenangan suami atas kelakuan istrinya, maka yang ditinggalkan adalah hal yang menunjukkan ketidaksenangan suami itu. ${ }^{37}$ Kalau seorang suami berada di dalam kamar dan tidur bersama, tetapi tidak ada cumbu, kata-kata manis, dan juga hubungan seks, maka itu telah menunjukkan bahwa istri tidak lagi berkenan di hati suaminya. ${ }^{38}$

3. pukullah mereka

Apabila cara yang kedua tidak berhasil, maka terdapat cara selanjutnya yaitu dengan cara memukul. Cara ini memukul bukan berarti menyakiti, akan tetapi memukul dalam artian mendidik, yakni pukulan yang tidak berlebihan sekiranya tidak menyakiti dan membahayakan. ${ }^{39}$ Tidak mematahkan tulangnya dan tidak mengeluarkan darah ditubuhnya serta tidak memukul mukanya, karena hal itu telah dilarang. ${ }^{40}$

Bila dengan pukulan ringan tersebut istri telah kembali kepada keadaan semula, yakni kembali taat pada suaminya dan masalah telah dapat diselesaikan, suami tidak boleh mencari kesalahan istri yang menimbulkan perselisihan lagi. ${ }^{41}$

36 M.Rasyid Ridha, al-Nida' li al-Jinsi al-Latif, A.Rivai Usman, Perempuan Sebagai Kekasih, (Jakarta: Hikmah, 2004), 82.

${ }^{37}$ Quraish Shihab, Tafsir al-Misbah volume 2, (Jakarta: Lentera Hati, 2002), 431.

${ }^{38}$ Ibid,.

${ }^{39}$ Ibnu Mas'ud dan Zainal Abidin, Fiqh Madzhab Syafii 2, 334.

${ }^{40}$ Imam al-Ghazali, Ibya' 'Ulumu al-Din, Zuhri, (Semarang: asy-Syifa', 2003), 160.

${ }^{41}$ Mahmud Yunus, Hukum Perkawinan dalam Islam, (Jakarta: Hidakarya Agung, 1981), 107. 
Adapun kalau nushuz itu dilakukan oleh pihak suami, maka keduanya tidak mengapa melakukan perdamaian sebagaimana dijelaskan dalam surat an-Nisa' ayat 128:

"Maka tidak mengapa bagi keduanya Mengadakan perdamaian yang sebenar-benarnya, dan perdamaian itu lebih baik (bagi mereka) walaupun manusia itu menurut tabiatnya kikir. dan jika kamu bergaul dengan isterimu secara baik dan memelibara dirimu (dari nusyuz, dan sikap tak acub), Maka Sesunggubnya Allah adalah Maha mengetahui apa yang kamu kerjakan." ${ }^{2}$

Maksud perdamaian ini adalah dalam bergilir dan pemberian nafkah, misalnya dengan sedikit mengalah dari pihak istri demi mempertahankan kerukunan. Jika istri bersedia, maka dapatlah dilangsungkan perdamaian itu. ${ }^{43}$ Adapun yang dimaksud dengan sulh sebagai suatu solusi sebagaimana disebutkan dalam ayat itu adalah perundingan yang membawa kepada perdamaian sehingga suami tidak sampai menceraikan istrinya, diantaranya dengan kesediaan istri untuk dikurangi hak materi dalam hal nafkah atau kewajiban non-materi, dalam arti kesediaan untuk memberikan giliran bermalamnya untuk digunakan suami kepada istrinya yang lain. Cara ini temasuk salah satu langkah untuk menghindari terjadinya perceraian. ${ }^{44}$

Ibnu katsir menjelaskan dalam kitabnya Tafsir al-Quran al'Azim, bahwa perdamaian di saat saling bertolak belakang adalah lebih baik daripada perceraian. ${ }^{45}$ Sayyid Sabiq menyatakan dalam Fiqh Sunnah, bahwa jika istri takut terhadap nushuz dari suaminya dan takut suaminya meninggalkan karena ia sakit, usianya sudah tua, dan wajahnya kurang menarik, maka keduanya boleh menjalin kesepakatan damai. Walaupun dalam

${ }^{42}$ Kementerian Agama RI, al-Qur'an dan Terjemahnya, 80.

43 Jalaluddin al-Mahalli dan Jalaluddin as-Suyuti, Tafsir al-Quran al-'Azim, (Surabaya: al-Hidayah, t.t), 89.

${ }^{44}$ Mahmud Yunus, Hukum Perkawinan dalam Islam, (Jakarta: Hidakarya Agung, 1981), 109.

45 Al-Imam Abi al-Fida' al-Hafiz Ibnu Katsir al-Damashqi, Tafsir al-Quran al'Ažim juz. 1, (Beirut: al-Nur al-'Ilmiyyah, 1992), 562. 
kesepakatan damai tersebut sang istri cenderung melepaskan sebagian haknya untuk kerelaan suaminya. ${ }^{46}$

\section{Akibat Nushuz}

Menurut jumhur ulama, suami tidak wajib memberi nafkah terhadap istri yang nusbu\%. Alasan jumhur adalah, bahwa nafkah yang diterima istri merupakan imbalan dari ketaatan yang diberikannya kepada suami. ${ }^{47}$ Istri yang nushuz hilang ketaatannya pada saat itu, oleh karena itu ia tidak berhak atas nafkah selama nushur, dan kewajiban suami kembali setelah nushuz berhenti.

Ulama Zahiriah berpendapat, bahwa istri yang nushuz, tidak gugur haknya dalam menerima nafkah, alasannya karena nafkah itu diwajibkan atas dasar akad nikah bukan ketaatan. Bila suatu waktu ia tidak taat kepada suaminya atau nushus, ia hanya dapat diberi pengajaran, seperti pisah tempat tidur, atau pukulan yang tidak menyakiti. ${ }^{48}$

Apabila suami tidak memberi nafkah kepada istri yang tidak nushuz. Jumhur ulama berpendapat, bahwa istri yang tidak mendapat nafkah dari suaminya, berhak tidak memberikan pelayanan kepada suaminya, bahkan boleh memilih untuk pembatalan perkawinan atau faskh. ${ }^{49}$ Ulama Zahiriyah berpendapat, bahwa istri yang tidak menerima nafkah dari suaminya, tetap menjalankan kewajiban sebagai istri dan tidak boleh menolak permintaan suami untuk digauli. ${ }^{50}$

\section{Latar Belakang Munculnya Counter Legal Drafting Kompilasi Hukum Islam}

KHI ditetapkan dengan Intruksi Presiden Nomor 1 Tahun 1991 oleh Presiden Soeharto. Dalam kenyataan yuridis, KHI

46 Sayyid Sabiq, Fiqh Sunnah, Jilid 3, Abu Syauqina dan Abu Aulia Rahma, Jilid 3, (Jakarta: Tinta Abadi Gemilang, 2003), 617.

47 Amir Syarifuddin, Hukum Perkawinan Islam di Indonesia, Jakarta: Kencana, 2009), 173.

48 Ibnu Hazmin, al-Muballa, (Mesir: Matba'ah al Jumhuriyah al-Arabiyah, 1970), 254.

${ }^{49}$ Ibnu Qudamah, al-Mughny, ( Cairo: Matba'ah al-Qahirah, 1969), 242.

${ }^{50}$ Ibnu Hazmin, 25. 
adalah satu-satunya materi Syai'at Islam yang dijadikan hukum positif di Indonesia. Meskipun landasan hukumnya tidak terlalu kuat, kenyataan di lapangan terlihat sangat efektif digunakan oleh para hakim agama dan pejabat KUA, bahkan masyarakat luas. ${ }^{51}$ Usia yang sudah cukup tua ini menuntut peninjauan ulang, karena KHI adalah karya para intelektual manusia yang bersifat relatif, dan juga bukan merupakan karya final dan mutlak. Oleh karena itu, KHI masih terbuka untuk ditinjau kembali. ${ }^{52}$

Pada tanggal 4 Oktober 2004, Kelompok Kerja Pengarusutamaan Gender Departemen Agama RI yang selanjutnya disebut Pokja PUG Depag, ${ }^{53}$ meluncurkan naskah tandingan rumusan hukum Islam yang disebut Counter Legal Draft Kompilasi Hukum Islam (CLD-KHI) sebagaimana respon atas Rancangan Undang-Undang Hukum Terapan Peradilan Agama, karena tim CLD-KHI berpandangan, bahwa RUU tersebut tidak sesuai dengan sistem hukum nasioanal dan bisa dinilai membuat diskriminasi terhadap warga negara non-muslim. Karena ini dapat menggoyahkan pilar pluralism dan demokrasi dalam kehidupan bangsa berdasarkan pancasila. Ketakutan ini dijadikan dasar oleh tim CLD-KHI untuk menyusun naskah yang pluralis, demokratis, dan humanis, dan adil gender. ${ }^{54}$

Counter Legal Draft Kompilasi Hukum Islam (CLD-KHI) merupakan hasil dari serangkaian pertemuan dan diskusi yang dimaksudkan untuk merombak dan mendesain ulang Kompilasi Hukum Islam (KHI). KHI dinilai sudah waktunya untuk diperbaharui seiring dengan perkembangan zaman. Perombakan

51 Tim Pengarusutamaan Gender Departemen Agama RI, Pembaruan Hukum Islam: Counter Legal Draft Kompilasi Hukum Islam, 2.

52 Abdurrahman, Kompilasi Hukum Islam di Indonesia, Jakarta: Akademika Presindo, 1992), 6.

${ }^{53}$ Pokja PUG Depag adalah suatu unit kerja yang diangkat oleh Menteri Agama RI untuk terselenggaranya perencanaan, penyusunan, pelaksanaan, pemantauan, dan evaluasi atas kebijakan dan program pembangunan nasional yang berprespektif gender dalam rangka mewujudkan kesetaraan dan keadilan gender dalam kehidupan berkeluarga, bermasyarakat, berbangsa, dan bernegara di lingkungan Departemen Agama.

54 Tim Pengarusutamaan Gender Departemen Agama RI, Pembaruan Hukum Islam: Counter Legal Draft Kompilasi Hukum Islam,(Jakarta: 2004), 3. 
dilakukan tidak hanya pada sisi material yang tertera dalam pasal demi pasal KHI, melainkan juga pada paradigmanya. Oleh karena itu, naskah CLD-KHI tidak hanya memuat perubahan-perubahan dari batang tubuh KHI dalam wujud Counter Legal Draft, akan tetapi juga menyertakan bangunan metodologi yang menjadi acuan kerja pembaharuan tim ini.

Tim penyusun CLD-KHI mempunyai alasan mendasar perlunya pembaruan Hukum Keluarga Islam di Indonesia. Alasanalasan tersebut sebagai berikut:

1. KHI diajukan oleh Depag RI untuk ditingkatkan statusnya, yang semula Inpres menjadi RUU HTPA. Tidak sampai disitu, bahkan buku ketiga dari KHI (tentang hukum Perwakafan) ditetapkan menjadi UU Wakaf sejak tahun 2004 dengan istilah UU Nomor 41 Tahun 2004. ${ }^{55}$ Marzuki Wahid menjelaskan dalam bukunya Fiqh Indonesia, bahwa dengan alasan ini, dalam konteks upaya mempengaruhi kebijakan hukum, KHI sudah di depan mata untuk direspon. ${ }^{56}$

2. KHI adalah satu-satunya ketentuan Syari'at Islam yang telah diakui negara dan sering dijadikan rujukan para hakim pengadilan agama, pejabat KUA, dan masyarakat. Hal ini dikarenakan KHI disusun berbahasa Indonesia sehingga mudah untuk dipahami. Selain itu, KHI juga memberikan kepastian hukum karena tidak menawarkan pilihan hukum lebih dari satu sebagaimana tradisi fiqh yang tercantum dalam kitab kuning. Meskipun dalam konteks politik hukum KHI fakultatif, tetapi kenyataan di lapangan KHI nyaris seolah-olah imperatif digunakan para hakim Pengadilan Agama. ${ }^{57}$

3. KHI tidak paralel dengan produk perundang-undangan, baik dalam hukum nasional maupun internasional yang telah diratifikasi. Dalam konteks Indonesia, KHI berseberangan dengan UU Nomor 7 Tahun 1984 yang mengatur tentang penghapusan segala bentuk diskriminasi terhadap perempuan, UU Nomor 39 Tahun 1999 tentang Hak Asasi Manusia, dan UU Nomor 23 Tahun 2002 tentang perlindungan anak yang

${ }^{55}$ Ibid.

${ }^{56}$ Marzuki Wahid, Fiqh Indonesia, 207.

57 Ibid,. 
isinya mengakui hak-hak perempuan dan anak sebagai hak asasi manusia serta adanya jaminan perlindungan yang kuat dari UU tersebut. Dalam konteks internasional, KHI juga bertentangan dengan Konvensi yang telah diratifikasi, yakni mengenai Penghapusan Segala Bentuk Diskriminasi Terhadap Perempuan, Convention on the Elimination of All Forms of Diskrimination Against Women (CEDAW). Begitu juga dengan beberapa instrument penegakan dan perlindungan HAM lain, seperti Deklarasi Universal HAM (1948), konvenan internasional tentang hakhak sipil dan politik yang sekarang sudah diratifikasi ke dalam UU Nomor 12 Tahun 2005, konvenan Internasional tentang hak-hak ekonomi, sosial dan budaya yang sekarang sudah diratifikasi ke dalam UU Nomor 11 Tahun 2005. ${ }^{58}$

4. KHI memiliki kelemahan pokok pada rumusan visi dan misinya, karena beberapa pasal dalam KHI secara prinsipil bertentangan dengan nilai-nilai dasar Islam yang universal, seperti prinsip persamaan (al-Musawah), persaudaraan (alUkhuwwah), dan keadilan (al-'Adalab). ${ }^{59}$

5. KHI dari sudut metodologi masih terkesan replika hukum fikih ulama zaman dahulu. Kontruksi hukum KHI belum dikerangkakan sepenuhnya dalam sudut pandang masyarakat Islam Indonesia, tetapi masih mencerminkan penyesuaian pada fikih timur tengah dan dunia arab lainnya. ${ }^{60}$

Berdasarkan alasan inilah tim CLD-KHI memilih naskah KHI sebagai basis kajian dalam perumusan tawaran-tawaran baru mengenai hukum keluarga Islam di Indonesia.

\section{Konsep Nushuz dalam CLD-KHI}

Tim pengarusutamaan gender Departemen Agama RI atau disebut Pokja PUG Depag RI dalam menyusun CLD-KHI memiliki beberapa tawaran pemikiran mengenai hukum keluarga Islam. Berdasarkan alasan-alasan di atas, tim CLD-KHI

58 Mubarok, "Relasi Suami Istri dalam Prespektif CLD KHI", Hukum Islam, 2 (Oktober, 2007), 198.

${ }_{59}$ Marzuki Wahid, Fiqh Indonesia, 208.

60 Tim Pengarusutamaan Gender Departemen Agama RI, Pembaruan Hukum Islam: Counter Legal Draft Kompilasi Hukum, 7-8. 
menawarkan pembaharuan hukum perkawinan, hukum kewarisan, dan hukum perwakafan. Ketiga bidang ini tercantum dalam tiga buku: buku pertama mengenai RUU Hukum Perkawinan Islam, buku kedua mengenai RUU Hukum Kewarisan Islam, dan buku ketiga mengenai RUU Hukum kewarisan. Marzuki Wahid menjelaskan dalam bukunya Fiqh Indonesia mengenai 23 tawaran pemikiran oleh CLD KHI. Tawaran pemikiran di bidang nushuz,menjadi tawaran yang keenam belas.

Dalam buku 1 (perkawinan), ketentuan umum Pasal 1 ayat (13) CLD-KHI menyatakan bahwa "nushuz adalah pembangkangan suami atau istri terhadap pasangannya karena tidak melaksanakan kewajiban sebagai suami atau istri atau melanggar hak pasangannya". ${ }^{1}$ Selain ketentuan tersebut, terdapat beberapa pasal yang terkait dengan nushur, yaitu pasal-pasal tentang Hak dan Kewajiban Suami Istri. Dalam pasal ini dinyatakan:

\section{Pasal 49}

1. Kedudukan, hak, dan kewajiban suami istri adalah setara, baik dalam kehidupan keluarga, maupun dalam kehidupan bersama si masyarakat.

2. Suami istri memiliki hak dan kewajiban untuk menegakkan kehidupan keluarga sakinah yang didasarkan pada mawaddah, rahmah, dan mashlahah.

\section{Pasal 50}

1. Suami dan istri masing-masing berhak:
a. Memiliki usaha ekonomi produktif
b. Melakukan perbuatan hukum
c. Memilih peran dalam kehidupan masyarakat

2. Suami dan istri secara bersama-sama berhak:

a. Memilih peran dalam kehidupan keluarga

b. Menentukan jangka waktu perkawinan

c. Mementukan pilihan memiliki keturunan atau tidak

d. Menentukan jumlah anak, jarak kelahiran, dan alat kontrasepsi yang dipakai

e. Menentukan tempat kediaman bersama

61 Tim Pengarusutamaan Gender Departemen Agama RI, Pembaruan Hukum Islam: Counter Legal Draft Kompilasi Hukum, 35. 
3. Hak dimiliki oleh kedua belah pihak setelah akad perkawinan dilangsungkan

Pasal 51

1. Suami dan istri berkewajiban:

a. Saling mencintai, menghormati, menghargai, melindungi, dan menerima segala perbedaan yang ada

b. Saling mendukung dan memberikan segala keperluan hidup keluarga sesuai dengan kemampuan masing-masing

c. Mengelola urusan kehidupan keluarga berdasarkan kesepakatan bersama

d. Saling memberikan kesempatan untuk mengembangkan potensi diri

e. Mengasuh, memelihara, dan mendidik anak-anak mereka

2. Kewajiban tersebut belaku bagi kedua belah pihak setelah akad perkawinan dilangsungkan

Pasal 52

1. Hamil, melahirkan dan menyusui yang melekat pada istri senilai dengan pekerjaan pencarian nafkah

2. Akibat dari ayat (1) pasal ini, istri berhak memperoleh imbalan yang seimbang sesuai dengan kesepakatan kedua belah pihak

3. Apabila kesepakatan tidak tercapai, maka masing-masing pihak dapat mengajukan permohonan penyelesaian ke pengadilan.

Menurut KHI, nushuz hanya dimungkinkan oleh istri. Hal ini diatur dalam pasal 84 ayat (1). Dalam pasal 84 tersebut dijelaskan seperti berikut ini:

1. Istri dapat dianggap nushuz jika ia tidak mau melaksanakan kewajiban-kewajiban sebagaimana dimaksud dalam pasal 83 ayat (1) kecuali dengan alasan yang sah

2. Selama istri dalam nushur, kewajiban suami terhadap istrinya tersebut pada pasal 80 ayat (4) huruf a dan b tidak berlaku kecuali hal-hal untuk kepentingan anknya

3. Kewajiban suami tersebut pada ayat (2) diatas berlaku kembali sesudah istri tidak nushuz

4. Ketentuan tentang ada atau tidak adanya nushuz dari istri harus didasarkan atas bukti yang sah. 
Sedangkan menurut CLD-KHI, nushur juga bisa dilakukan suami, yang mana hal ini diatur dalam pasal 53 ayat (1) CLD-KHI (Buku Perkawinan) berikut ini:

1. Suami atau istri dapat dianggap nu₹̧иz apabila tidak melaksanakan kewajiban atau melanggar hak sebagaimana diatur dalam pasal 50 dan 51

2. Penyelesaian nushuz dilakukan secara damai dengan musyawarah keluarga

3. Apabila tidak tercapai penyelesaian damai, maka pihak yang dirugikan dapat mengajukan permohonan atau gugatan penyelesaian kepada pengadilan

4. Apabila terjadi kekerasan atau penganiayaan akibat nushur, maka pihak yang dirugikan dapat melaporkan kepada kepolisian sebagai tindak pidana.

\section{Konsep Nushuz dalam CLD-KHI Perspektif Hukum Islam}

Kompilasi Hukum Islam (KHI) ditetapkan dengan Intruksi Presiden No. 1 Tahun 1991 yang berisi kumpulan peraturan hukum keluarga Islam. KHI juga dipakai sebagai pegangan para hakim Pengadilan Agama di Indonesia untuk mengatasi masalah keluarga, termasuk didalamnya masalah nushuг: Nushuz dalam KHI diatur dalam pasa 77-84. KHI mengatur mulai dari hak dan kewajiban suami istri demi mewujudkan keluarga yang sakinah, mawaddah, dan rahmah. Apabila seorang istri tidak melaksanakan kewajibannya sebagai istri atau melanggar hak suami, maka dapat dianggap nushuz, sedangkan jika perbuatan tersebut dilakukan oleh suami, tidak diatur dalam KHI. Hal inilah yang menyebabkan munculnya naskah tandingan Hukum Keluarga Islam yang dibuat pada tahun 2004 oleh Tim Pengarusutamaan Gender Departemen Agama R.I. dengan istilah Counter Legal Draft Kompilasi Hukum Islam ( CLD-KHI).

Tim penyusun CLD-KHI menganggap, bahwa konsep nushuz dalam KHI tidak ada unsur keadilan, dalam arti lebih mengunggulkan laki-laki daripada perempuan. Bahkan tidak ada konsekuensi bagi seorang suami yang tidak melaksanakan kewajiban sebagai suami atau melanggar hak istri. Karena seorang suami juga manusia yang tak luput dari salah, sengaja atau tidak. 
Konsep nushuz dalam CLD-KHI bermula dari aturan tentang hak dan kewajiban suami istri yang setara, dalam arti keduanya boleh mengambil peran masing-masing baik sebagai kepala keluarga yang bertugas menafkahi kebutuhan keluarga ataupun di rumah saja. Dari istilah kesetaraan ini, apabila kemudian salah satu dari keduanya tidak melaksanakan kewajiban atau melanggar hak pasangannya dapat di anggap nushuz. Hal ini diatur dalam pasal 4953 CLD-KHI (buku perkawinan).

Dalam al-Qur'an dijelaskan mengenai nushuz istri dan nushuz suami. Nushuz yang dilakukan oleh istri dijelaskan pada surat anNisa' ayat 34 yang artinya:

"Kaum laki-laki itu adalah pemimpin bagi kaum wanita, oleh karena Allab telah melebibkan sebahagian mereka (laki-laki) atas sebabagian yang lain (wanita), dan karena mereka (laki-laki) telab menafkabkan sebagian dari harta mereka. sebab itu Maka wanita yang saleh, ialah yang taat kepada Allah lagi memelihara diri ketika suaminya tidak ada, oleh karena Allah telah memelihara (mereka). wanita-wanita yang kamu khawatirkan nushuznya, Maka nasehatilah mereka dan pisabkanlah mereka di tempat tidur mereka, dan pukullah mereka. kemudian jika mereka mentaatimu, Maka janganlah kamu mencari-cari jalan untuk menyusabkannya. Sesunggubnya Allah Maha Tinggi lagi Maha besar". ${ }^{62}$

Ayat ini menjelaskan bahwa jika seorang wanita berbuat nushu>z maka suami harus menasihati, apabila dengan menasihati belum bisa membuat istri kembali patuh, maka angkah kedua suami memalingkan ditempat tidur, apabila langkah kedua tidak berhasil, selanjutnya dengan cara memuku, akan tetapi pukulan yang bersifat menddik dan tidak sampai menyakiti istri. Apabila istri telah taat kembali, suami tidak boleh mencari kesalahan istri.

berikut ini:

Hadits Nabi Saw. Juga menjelaskan mengenai nuг̆uг istri "Menceritakan kepada kami Mubammad bin Basyar telah menceritakan kepada kami Abdul Wabhab telab mengabarkan kepada kami Ayyub dari Ikrimah bahwa Rifa'ah telah menceraikan isterinya, kemudian isterinya menikah dengan Abdurrabman bin Zubair Al Qurdli, Aisyah berkata;

${ }^{62}$ Kementerian Agama RI, al-Qur'an dan Terjemabnya, 80. 
"Ketika itu mantan isteri Rifa'ah tengah mengenakan kerudung hijau, lalu mantan isteri Rifa'ah mengadukan permasalabannya kepada Aisyah, mantan isteri Rifaah memperlihatkan bekas bijau di kulitnya. Ketika Rasulullah shallallahu 'alaibi wasallam datang -kala itu para wanita membela satu sama lainnya. Kata 'Aisyah 'Sungguh yang kulihat padanya, seperti yang ditemui wanita mukminab lainnya, sungguh kulitnya jaub lebih bijau dari pada bajunya. Kata Ikrimah, tiba-tiba Abdurrahman datang bersama dua anaknya yang di basilk.an bukan dari isteri keduanya (mantan isteri Rifa'ah). Isterinya berkata; "Demi Allah, tidaklah aku berdosa ketika bersamanya melainkan karena ia tidak dapat memuaskan diriku." Sambil memegang ujung kainnya. Abdurrahman berkata; "Demi Allab, ia dusta wahai Rasulullah, sesunggubnya aku dapat memuaskannya, akan tetapi ia berbuat nusyuz. (membangkang terhadap perintah suami) karena ia bendak kembali kepada Rifa'ab. ${ }^{63}$

Hadits ini menjelaskan, bahwa Rifa'ah telah menceraikan istrinya, kemudian mantan istri Rifa'ah menikah dengan Abdurrahman. Mantan istri Rifa'ah mengadukan permasalahan yang dialaminya kepada Siti Aisyah, dengan memperlihatkan bekas hijau dikulitnya. Mantan istri rifa'ah mengatakan kepada Rasulullah Saw. Bahwa suaminya (Abdurrahman) tidak bisa memuaskan dirinya, akan tetapi Abdurrahman menyangkal perkataan istrinya. Abdurrahman berkata bahwa ia dapat memuaskan istrinya, akan tetapi istrinya telah berbuat nushuz karena hendak kembali kepada Rifa'ah.

Nu₹huz suami dijelaskan daam surat an-Nisa' ayat 128 yang artinya:

"Dan jika seorang wanita khawatir akan nushuz, atau sikap tidak acuh dari suaminya, Maka tidak mengapa bagi keduanya Mengadakan perdamaian yang sebenar-benarnya, dan perdamaian itu lebih baik (bagi mereka) walaupun manusia itu menurut tabiatnya kikir. dan jika kamu bergaul dengan isterimu secara baik dan memelihara dirimu (dari nushuz dan sikap tak acuh), Maka

${ }^{63}$ Sahih Bukhari, Kitab Sembilan Imam Hadits, No. 5377 lidwa pusaka i-software www.lidwapusaka.com 
Sesungguhnya Allah adalah Maha mengetahui apa yang kamu kerjakan". ${ }^{64}$

Ayat ini menjelaskan, jika seorang wanita khawatir akan nushuz, yang dilakukan oleh suaminya, maka keduanya diperbolehkan mengadakan perdamaian. Karena hal itu yang lebih baik untuk mereka.

Begitu juga dalam hadits Nabi SAW. menyatakan:

"Telah menceritakan kepada kami Abmad bin Yunus, telah menceritakan kepada kami Abdurrabman bin Abu Az Zinad dari Hisyam bin 'Urwah dari ayahnya, ia berkata; Aisyah berkata; wahai anak saudariku, Rasulullah shallallabu 'alaibi wasallam tidak melebibkan sebagian kami atas sebagian yang lain dalam membagi waktu tinggalnya bersama kami. Setiap hari beliau mengelilingi kami semua dan mendekat kepada seluruh isteri tanpa menyentuh hingga sampai kepada rumah isteri yang hari itu merupakan bagiannya, kemudian beliau bermalam padanya. Sungguh Saudah binti Zam'ah ketika telah berusia lanjut dan takut ditinggalkan Rasulullah shallallahu 'alaibi wasallam, ia berkata; wahai Rasulullah, bariku untuk Aisyah. Dan Rasulullah shallallabu 'alaibi wasallam menerima hal tersebut. Ia berkata; kami katakan; mengenai hal tersebut dan orang yang semisalnya, Allah Ta'ala menurunkan ayat: "Dan jika seorang wanita khawatir akan nusyuz: "65

Hadits ini menjelaskan, bahwa istri Rasulallah Saw. yang bernama Siti Saudah binti Zam'ah memberikan jatah harinya bersama Rasulullah Saw. Kepada Siti Aisyah. Hal ini diberikan karena Siti Saudah dengan usianya yg telah lanjut takut diceraikan oleh Rasulullah Saw. Kemudian Rasululah Saw. menerima permintaan dari Siti Saudah Binti Zam'ah.

Menurut Imam Syafi'i, istri dapat dikatakan nushur apabila keluar rumah tanpa izin suami, tidak mau digauli, berangkat haji tanpa seizin suami. Begitu juga menurut Imam Abu Hanifah, istri dikatakan nushuz apabila keluar dari rumah, menolak pindah rumah, berangkat haji, dan juga wanita karir.

${ }^{64}$ Kementerian Agama RI, al-Qur'an dan Terjemahnya, 80.

65 S \}unan Abu Daud, Kitab Sembilan Imam Hadits, No. 1823 lidwa pusaka isoftware www.lidwapusaka.com 
Seorang suami dapat dikatakan nuгhuz jika tidak mau memberi nafkah terhadap istri yang taat, tidak mau menggauli istri, menyakiti istri dengan tanpa alasan, dan juga bersikap acuh tak acuh. ${ }^{66}$

Menurut penulis, tawaran pemikiran mengenai konsep nushuz oleh CLD KHI belum sesuai dengan Hukum Islam, meskipun nushuz diberlakukan bagi suami maupun istri. Begitu juga dengan penyelesaian nushuz suami yang dilaksanakan dengan perdamaian. Proses yang dijelaskan dalam al-Qur'an tidak semata-mata menyimpan unsur kekerasan. Bermula dari menasihati, memalingkan di tempat tidur, dan memukul. Istilah memukul ini tidak seperti pukulan yang keras sehingga bisa menyakiti istri, melainkan sebuah pukulan yang bersifat mendidik.

Adanya nushuz disebabkan oleh salah satu pihak tidak melaksanakan kewajiban atau melanggar hak pasangannya. Dari sisi konsep hak dan kewajiban suami-istri, CLD KHI mensetarakan keduanya, sedangkan dalam Islam, hak dan kewajiban suami istri berbeda. Begitu pula mengenai akibat daripada nushuz itu sendiri, dalam CLD KHI tidak dijelaskan. inilah yang menurut penulis tidak sesuai dengan hukum Islam.

Menurut jumhur ulama, suami tidak wajib memberi nafkah ketika istri nushuz, karena nafkah yang diterima istri itu merupakan ketaatan yang diberikannya kepada suami. Apabila suami tidak memberikan nafkah kepada istri yang taat (tidak nushus), jumhur ulama berpendapat, istri berhak tidak memberikan pelayanan kepada suaminya, bahkan boleh memilih untuk pembatalan perkawinan atau faskh. ${ }^{67}$

Aturan dalam al-Qur'an, Hadits, maupun pendapat ulama, sangat menjunjung tinggi nilai-nilai keadilan. Tidak ada kesenjangan sosial, apalagi sampai menjatuhkan martabat manusia, baik laki-laki maupun perempuan.

\section{Penutup}

Konsep nushuz yang diatur dalam CLD-KHI merupakan konsep yang berasaskan keadilan gender dan penegakan HAM.

${ }^{66}$ Al-Bagawi, at-Tabdriib fi Fiqh al-Imam asy-Syafi'i, 545.

${ }^{67}$ Ibnu Qudamah, al-Mughny, (Cairo: Matba’ah al-Qahirah, 1969), 242. 
Seorang suami dan istri masing-masing mempunyai peran yang sama, bahkan nushuz berlaku pada keduanya apabila salah satu meninggalkan kewajiban atau melanggar hak pasangannya. penyelesaian nushuz dilakukan dengan cara perdamaian, baik dilakukan oleh pihak istri maupun suami.

Konsep nushuz dalam CLD-KHI adalah belum sesuai dengan hukum Islam, meskipun dengan adanya nushur suami dan istri. Karena adanya nusbuz disebabkan oleh salah satu pihak yang tidak melaksanakan kewajiban atau melanggar hak pasangannya. CLD KHI mensetarakan hak dan kewajiban suami-istri, sedangkan Hukum Islam membedakan keduanya. Cara penyelesaian nushuz juga tidak sama. Dalam Hukum Islam, penyelesaian nushuz yang dilakukan oleh istri ada tiga tahap, yakni mulai menasehati, meninggalkan di tempat tidur, dan memukul dengan pukulan yang tidak keras. Sedangkan penyelesaian nushuz yang dilakukan oleh suami dengan cara perdamaian. Begitu juga dengan akibat nushur, dalam CLD-KHI tidak dijelaskan.

Dalam merencanakan perubahan hukum, khususnya pada hukum keluarga Islam, sebaiknya melibatkan berbagai pakar hukum Islam yang betul-betul memahami hukum keluarga Islam. Perlu juga melibatkan para pejabat yang berwenang agar membantu mensosialisasikan kepada masyarakat tentang konsep nushuz, dalam CLD-KHI. Seharusnya konsep nusbuz dalam CLDKHI, diatur lebih detail lagi, mulai dari pemenuhan hak dan kewajiban suami istri hingga berakhir pada akibat daripada perbuatan nushuz yang dilakukan oleh kedua belah pihak.

\section{Daftar Pustaka}

Abdul Aziz Dahlan et al.. Ensiklopedi Islam, jilid 4, Jakarta: Ichtiar Baru Van Hoeve, 2005.

Abdul Rahman Ghozali. Fiqh Munakahat, Jakarta: Kencana Perdana Media Grup, 2012.

Abdurrahman. Kompilasi Hukum Islam di Indonesia, Jakarta: Akademika Presindo, 1992.

Abu Abdillah Muhammad bin Idris al-Syafi'i. al-Umm, Bairut: Dar al-Fikr, 1999. 
Abu Zakaria Muhy al-Din bin Syaraf al-Nawawi. al-Majmu' sharh almubadhdhab, vol.16, Bairut: Dar al-Fikr, t.t..

Al Qurtubi. al-Jami' Li abkam al-Qur'an, juz 5, Bairut: Dar al-Fikr, 2000.

Al-Bagawi. at-Tahdziib fi Fiqh al-Imam asy-Shafi'i, Beirut: Dar al-Kutub al-Imiyyah, 1997.

Al-Imam Abi al-Fida' al-Hafiz Ibnu Katsir al-Damashqi. Tafsir alQuran al-'Ažim juz 1, Beirut: al-Nur al-'Ilmiyyah, 1992.

Amir Syarifuddin. Hukum Perkawinan Islam di Indonesia, Jakarta: Kencana, 2009.

Departemen Agama R.I, Bahan Penyuluhan Hukum, Jakarta: Direktorat Jenderal Pembinaan Kelembagaan Agama Islam, 1999.

Ibn manzur. Lisan al-'Arab, juz 7, Bairut: Dar al-Misriyyah, 1999.

Ibnu Hazmin. al-Muballa, Mesir: Matba'ah al Jumhuriyah alArabiyah, 1970.

Ibnu Mas'ud dan Zainal Abidin, Fiqh Madæhab Shafi'i 2, Bandung: Pustaka Setia, 2007.

Ibnu Qudamah, al-Mughny, Cairo: Matba'ah al-Qahirah, 1969.

Ibrahim al-Bajuri. Hashiyah al-Bajuri ala Ibn al-Qasim al-Ghazi, vol.2, Bairut: Dar al-Kutub al-Ilmiyyah, t.t..

Imam al-Ghazali, Ibya' 'Ulumu al-Din, Zuhri, (Semarang: asy-Syifa', 2003), 160.

Jalaluddin al-Mahalli dan Jalaluddin as-Suyuti. Tafsir al-Quran al'Ažim, Surabaya: al-Hidayah, t.t..

Kementerian Agama RI. al-Qur'an dan Terjemahnya, Bandung: Diponegoro, 2009.

M.Rasyid Ridha. al-Nida' li al-Jinsi al-Latif, A.Rivai Usman, Perempuan Sebagai Kekasih, Jakarta: Hikmah, 2004.

Mahmud Yunus. Hukum Perkawinan dalam Islam, Jakarta: Hidakarya Agung, 1981.

Marzuki Wahid, Fiqh Indonesia, Bandung: Marja, 2014.

Mubarok. "Relasi Suami Istri dalam Prespektif CLD KHI", Hukum Islam, 2 Oktober, 2007.

Muhammad Al Baqir. Menyingkap Hakikat Perkawinan, Bandung: Penerbit Karisma, 1997. 
Quraish Shihab, Tafsir al-Misbah volume 2, (Jakarta: Lentera Hati, 2002), 431.

Sahih Bukhari, Kitab Sembilan Imam Hadits, No. 5377 lidwa pusaka i-software www.lidwapusaka.com

Sayyid Sabiq, Fiqh Sunnah, Jilid 3, Abu Syauqina dan Abu Aulia Rahma, Jilid 3, Jakarta: Tinta Abadi Gemilang, 2003.

Shams ad-Din as-Sharakhsi. al-Mabsut, vol 5, Beirut: Dar al-Kutub al-Ilmiyyah, 1993.

Slamet Abidin dan Aminuddin. Figh Munakahat. Bandung: CV. Pustaka Setia, 1999.

Sudarsono. Pokok-Pokok Hukum Islam, Jakarta: Rineka Cipta, 1992.

Sunan Abu Daud, Kitab Sembilan Imam Hadits, No. 1823 lidwa pusaka i-software www.lidwapusaka.com

Tim Pengarusutamaan Gender Departemen Agama RI. Pembaruan Hukum Islam: Counter Legal Draft Kompilasi Hukum Islam, Jakarta: 2004.

Wahbah az-Zuhayly. al-Figh al-Islam wa Adillatuh, Damaskus: Dar al-Fikr,1997. 